\title{
Studi Komparatif Efektivitas Seftriakson dibanding Kombinasi Seftriakson- Metronidazole dan Sefuroksim-Metronidazole pada Pasien Apendisitis yang Menjalani Apendiktomi
}

\author{
Zulfa, I.M..$^{*}$, Ernawati, I. ${ }^{1}$, Handayani, W. ${ }^{2}$ \\ ${ }^{1}$ Bidang Ilmu Farmasi Komunitas, Akademi Farmasi Surabaya, Jl. Ketintang Madya No. 81, Surabaya, 60231 \\ ${ }^{2}$ Bidang Ilmu Farmasi Klinik, Akademi Farmasi Surabaya, Jl. Ketintang Madya No. 81, Surabaya, 60231 \\ ${ }^{*}$ Coressponding author e-mail: ililmaidatuz@gmail.com.
}

Riwayat artikel: Dikirim: 20-10-2019; Diterima: 20-01-2020, Diterbitkan: 21-01-2020

\begin{abstract}
ABSTRAK
Apendisitis atau inflamasi pada usus buntu masih memiliki tingkat kejadian yang relatif tinggi di Indonesia yaitu mencapai 3236 kasus pada 2103 dan 4351 kasus pada 2014. Penggunaan antibiotik pada apendisitis diberikan untuk mencegah surgical site infection (SSI) pasca apendiktomi. Golongan sefalosporin seperti seftriakson dan sefuroksim seringkali digunakan dalam bentuk tunggal maupun dalam kombinasi dengan imidazol seperti metronidazol. Studi ini bertujuan untuk membandingkan efektivitas antibiotik pada pasien apendisitis akut non perforasi yang menjalani apendiktomi dari parameter lama hari rawat, status pulang, prevalensi munculnya SSI. Observasi analitik dilakukan secara retrospektif pada rekam medis pasien apendisitis akut dengan kode ICD k35.8 dalam periode tahun 2018. Sebanyak 39 rekam medis pasien apendisitis akut telah dianalisis. Dari jumlah tersebut, 25 orang menerima terapi antibiotik tunggal seftriakson, 5 orang menerima kombinasi seftriaksonmetronidazol dan 9 orang menerima kombinasi sefuroksim-metronidazol. Seluruh antibiotik diberikan secara inravena yang diberikan sebagai profilaksis hingga pasca apendiktomi. Rata-rata lama hari rawat dari ketiga regimen menunjukkan kombinasi Sefuroksim-metronidazol memiliki lama hari rawat paling singkat $(3,00 \pm 0,50$ hari) sedangkan dalam status pulang terapi tunggal seftriakson paling banyak dinyatakan sembuh (64,00\%). SSI hanya ditemukan pada pasien yang menerima terapi tunggal seftriakson $(2,00 \%)$. Hasil analisis menunjukkan terdapat perbedaan yang signifikan dalam rata-rata lama hari rawat dan status pulang antar tiga regimen terapi ( $\mathrm{p}-$ value 0,$000 ; \mathrm{p}$-value 0,001). Terapi tunggal seftriakson maupun kombinasi sefuroksim-metronidazol dan seftriakson-metronidazol dirasa efektif untuk sebagai antibiotik profilaksis dan pasca apendiktomi pada apendisitis akut. Namun terkait perbedaan lama hari rawat yang signifikan, pemilihan antibiotik lebih lanjut lebih baik disertai perbandingan efektifitas dan biaya terapi.
\end{abstract}

Kata kunci: apendisitis, seftriakson, metronidazol, sefuroksim.

\section{ABSTRACT}

Appendicitis or inflammation of appendix still has high prevalence in Indonesia which reach 3236 cases in 2103 and increase at 4351 cases in 2014. Antibiotics are used in appendicitis to prevent surgical site infection (SSI) after appendictomy. Cephalosporins like ceftriaxone and cefuroxime are commonly used as monotherapy or in combination with imidazole. This study was aimed to compare the effectifity of antibiotics used in acute non perforation appendicitis patients who underwent appendictomy using parameter length of hospital stay, discharge status, and amount of SSI occurence. An analytical observation was conduct retrospectively through acute appendicitis patient medical records with ICD k35.8 during 2018. A total of 39 medical records were analyzed. Of that, 25 patients received ceftriaxone monotherapy, 5 patients received combination of ceftriaxone and metronidazole, and 9 remaining received cefuroxime in combination with metronidazole. All antibiotics were administered intravenously and used as prophylaxis and continued as pasca appendictomy therapy. The average of hospital stay of that three antibiotics regimen showed that the patients received combination of cefuroxime and metronidazole had the shortest period $(3.00 \pm 0,50$ days) while based on discharge status, patients with ceftriaxone monotherapy were the most who discharged to home with complete recovery $(64.00 \%)$. However, SSI occurence was only observed in patients received ceftriaxone monotherapy $(2.00 \%)$. Statistical analysis showed that there is a significant different in the average of hospital stay and discharge status through three groups of antibiotics treatment ( $\mathrm{p}$-value 0,$000 ; \mathrm{p}$-value 0,001 ). In conclusion, the three regimens of antibiotics are effective as prophylactic and post appendictomy in acute appendicitis. However, becuse of significant difference of hospital stay, antibiotics regimen selection should consider the cost and effectivity ratio analysis. 


\section{Zulfa, dkk.}

DOI : https://doi.org/10.24843/JFU.2019.v08.i02.p07

pISSN: 2301-7716; eISSN: 2622-4607

Jurnal Farmasi Udayana, Vol 8, No 2, Tahun 2019, 104-109

Keywords: appendicitis, ceftriaxone, metronidazole, cefuroxime.

\section{PENDAHULUAN}

Apendisitis disebut juga inflamasi pada usus

buntu. Usus buntu merupakan organ yang memiliki bentuk memanjang dengan panjang sekitar 6-9 $\mathrm{cm}$ yang terletak pada bagian pangkal usus besar [1]. Insiden appendisitis di dunia diestimasikan 86 kasus per tahun tiap 100.000 populasi [2]. Di Indonesia prevalensi apendisitis mencapai 4.351 kasus pada tahun 2014, hal ini terjadi kenaikan karena di tahun 2013 sebanyak 3.236 jiwa. Baik laki-laki maupun perempuan dapat terjangkit apendisitis, tetapi laki-laki memiliki kejadian lebih tinggi khususnya pada usia remaja dan dewasa [3].

Tindakan yang seringkali dilakukan untuk penanganan apendisitis adalah apendiktomi. Apendiktomi adalah pengangkatan appendiks dengan jalur pembedahan dengan membuka abdomen melalui pembedahan [4]. Surgical Site Infection (SSI) dapat muncul sebagai salah satu bentuk komplikasi dan ditengarai dapat meningkatkan lama hari rawat dan biaya perawatan [5]. SSI dapat muncul karena beberapa faktor seperti perdarahan karena hemostatis yang kurang sempurna, infeksi luka, jahitan kurang baik, dan teknik operasi yang kurang baik [6]. Untuk mencegah munculnya SSI, tindakan apendiktomi senantiasa disertai dengan pemberian terapi antibiotik pre dan pasca operasi terutama pada kasus apendisitis yang disertai dengan perforasi [7]. Meta-analisis yang melibatkan 45 penelitian menyebutkan secara keseluruhan antibiotik pre operatif efektif dalam mengurangi infeksi luka dan abses baik yang digunakan secara profilaksis (penggunaan dosis tunggal sebelum operasi) atau secara berulang terutama pada apendisitis dengan komplikasi [8]. Untuk pemberian antibiotik pasca operasi memang lebih disarankan pada apendisitis perforasi. Namun, penelitian oleh Lieberman et al. menyebutkan pasien apendisitis non perforasi yang diberikan dosis tunggal sefoksitin pre operatif mengalami SSI lebih tinggi dari pasien yang diberikan sefoksitin pre dan pasca operasi $(11,1 \%$ dibanding $1,9 \%)$ [9].

Pemberian antibiotik pre operatif yang disarankan dapat diberikan 1 jam sebelum insisi maupun hingga 24 jam setelah operasi berlangsung. Waktu pemberian antibiotik pre operatif yang tidak tepat akan berpengaruh pada munculnya SSI [10]. sedangkan untuk antibiotik pasca operasi dapat dilakukan secara intravena selama 1-3 hari atau minimal 3-5 hari untuk pasien dewasa kasus perforasi sampai tanda-tanda klinis seperti demam dan hasil laboratorium pada kurva protein dan sel darah putih mulai menurun [8]. Jenis antibiotik yang digunakan pada apendisitis dapat berupa bentuk tunggal maupun kombinasi. Sistematik review menyebutkan sefalosporin dan derivat imidazol adalah antibiotik yang paling sering digunakan pada apendisitis [8]. Seftriakson yang merupakan sefalosporin generasi ketiga yang seringkali digunakan dalam bentuk tunggal, sedangkan dalam regimen kombinasi seringkali digunakan kombinasi seftriakson dan metronidazol yang merupakan golongan imidazol serta kombinasi sefuroksim dan metronidazol.

Perbandingan efektivitas antibiotik pada apendisitis akut sangat penting dilakukan guna optimalisasi pilihan terapi. Lama hari rawat dan prevalensi munculnya SSI dapat digunakan sebagai parameter penilaian efektivitas antibiotik yang diberikan pada apendisitis akut. Dalam studi ini akan dikaji perbandingan efektivitas tiga regimen antibiotik untuk apendisitis akut yang diberikan sebagai antibiotik profilaksis serta sebagai antibiotik pasca apendiktomi di suatu rumah sakit di kota Surabaya.

\section{BAHAN DAN METODE \\ Bahan}

Studi observasional dilakukan secara retrospektif pada rekam medis pasien yang ditentukan melalui kriteria pemilihan sampel di salah satu rumah sakit di Kota Surabaya. Parameter efektifitas antibiotik yang diamati adalah lama hari rawat yang dihitung dari durasi tanggal masuk rumah sakit (MRS) hingga keluar rumah sakit (KRS), status pulang yang diklasifikasikan menjadi sembuh dan membaik (membaik adalah keadaan belum sembuh namun membaik bila dibandingkan dengan keadaan awal), serta munculnya SSI (dilihat dari lembar observasi SSI dalam rekam medis). Rekam medis pasien dengan data tidak lengkap akan di eksklusi.

\section{Metode}

Rekam medis pasien apendisitis akut non perforasi yang menjalani apendiktomi dengan 


\section{Zulfa, dkk.}

DOI : https://doi.org/10.24843/JFU.2019.v08.i02.p07

pISSN: 2301-7716; eISSN: 2622-4607

Jurnal Farmasi Udayana, Vol 8, No 2, Tahun 2019, 104-109

kode ICD k35.8 usia 15 tahun keatas baik perempuan maupun laki-laki yang menerima terapi antibiotik tunggal seftriakson, kombinasi seftriakson-metronidazol serta kombinasi sefuroksim-metronidazol sebagai antibiotik profilaksis dan terapi pasca apendiktomi dalam periode tahun 2018 diobservasi dalam penelitian ini secara total sampling. Ketiga parameter yang diamati dicatat dalam lembar rekap data. Perbandingan lama hari rawat ketiga kelompok pasien dianalisis melalui uji One Way $A N O V A$ menggunakan software SPSS-20. Nilai p-value $<0,05$ menunjukkan adanya perbedaan rata-rata lama hari rawat pasien secara statistik. Untuk perbedaan status pulang dan muncul atau tidaknya SSI dianalisis menggunakan uji Fisher exact test. Nilai p-value $<0,05$ menunjukkan perbedaan yang signifikan secara statistik.
Sebanyak 39 rekam medis pasien apendisitis akut telah dianalisis. Terapi tunggal seftriakson yang diberikan adalah dengan frekuensi 2 hingga 3 kali sehari dengan dosis tiap kali pakai yakni $1 \mathrm{~g}$ hingga $2 \mathrm{~g}$ sementara terapi kombinasi seftriaksonmetronidazol diberikan 2 kali sehari untuk seftriakson dan 3 kali sehari untuk metronidazol dengan dosis masing-masing $1 \mathrm{~g}$ hingga $1,5 \mathrm{~g}$ untuk seftriakson dan $500 \mathrm{mg}$ untuk metronidazol. Untuk terapi kombinasi Sefuroksim-metronidazol diberikan dengan frekuensi 2 hingga 3 kali sehari untuk Sefuroksim dan 3 kali sehari untuk metronidazol dengan dosis $1 \mathrm{~g}$ untuk Sefuroksim dan $500 \mathrm{mg}$ untuk metronidazol. Seluruh antibiotik diberikan secara inravena yang diberikan sebagai profilaksis hingga pasca apendiktomi. Distribusi karakteristik jenis kelamin dan usia pasien terdapat dalam Tabel 1.

\section{HASIL}

Tabel 1. Karakteristik Pasien

\begin{tabular}{|c|c|c|c|}
\hline Karakteristik & $\begin{array}{l}\text { Seftriakson } \\
n=25 \\
n(\%)\end{array}$ & $\begin{array}{c}\text { Seftriakson-Metronidazol } \\
\mathrm{n}=5 \\
\mathrm{n}(\%)\end{array}$ & $\begin{array}{c}\text { Sefuroksim-Metronidazol } \\
\mathrm{n}=9 \\
\mathrm{n}(\%)\end{array}$ \\
\hline \multicolumn{4}{|l|}{ Jenis Kelamin } \\
\hline Perempuan & $18(72,00)$ & $2(40,00)$ & $7(77,78)$ \\
\hline Laki-laki & $7(28,00)$ & $3(60,00)$ & $2(22,22)$ \\
\hline \multicolumn{4}{|l|}{ Usia } \\
\hline $15-25$ & $11(44,00)$ & $4(80,00)$ & $4(44,44)$ \\
\hline $26-35$ & $6(24,00)$ & $1(20,00)$ & $3(33,33)$ \\
\hline $36-45$ & $7(28,00)$ & - & - \\
\hline $46-55$ & - & - & - \\
\hline$>55$ & $1(4,00)$ & - & $2(22,22)$ \\
\hline
\end{tabular}

Tabel 2. Komparasi Efektivitas

\begin{tabular}{|c|c|c|c|c|}
\hline Parameter & $\begin{array}{c}\text { Seftriakson } \\
\mathrm{n}=25\end{array}$ & $\begin{array}{l}\text { Seftriakson- } \\
\text { Metronidazol } \\
n=5\end{array}$ & $\begin{array}{c}\text { Sefuroksim- } \\
\text { Metronidazol } \\
\mathrm{n}=9\end{array}$ & p-value \\
\hline $\begin{array}{l}\text { Lama Hari Rawat } \\
\text { (rata-rata hari } \pm \text { SD) }\end{array}$ & $4,24 \pm 1,05$ & $5,60 \pm 0,89$ & $3,00 \pm 0,50$ & 0,000 \\
\hline $\begin{array}{c}\text { Status Pulang } \\
\text { Sembuh } \\
\text { Membaik }\end{array}$ & $\begin{array}{c}16(64,00) \\
9(36,00)\end{array}$ & $\begin{array}{l}1(20,00) \\
4(80,00)\end{array}$ & $\begin{array}{c}0(0,00) \\
9(100,00)\end{array}$ & 0,001 \\
\hline $\begin{array}{l}\text { SSI } \\
\text { Tidak Muncul } \\
\text { Muncul }\end{array}$ & $\begin{array}{c}23(92,00) \\
2(8,00)\end{array}$ & $\begin{array}{c}5(100,00) \\
0^{`}(0,00)\end{array}$ & $\begin{array}{c}9(100,00) \\
0(0,00)\end{array}$ & 1,000 \\
\hline
\end{tabular}


DOI : https://doi.org/10.24843/JFU.2019.v08.i02.p07

pISSN: 2301-7716; eISSN: 2622-4607

Jurnal Farmasi Udayana, Vol 8, No 2, Tahun 2019, 104-109

\section{PEMBAHASAN}

Studi observasional retrospektif ini dilakukan untuk melihat perbandingan efektifitas pemberian antibiotik tunggal seftriakson dengan kombinasi seftriakson-metronidazol dan kombinasi sefuroksim-metronidazol pada pasien apendisitis di salah satu rumah sakit di Kota Surabaya. Parameter efektifitas yang digunakan pada penelitian ini diantaranya lama hari rawat, status pulang pasien dan ada atau tidaknya SSI (Tabel. 2). Berdasarkan hasil penelitian diketahui mayoritas pasien apendisitis menggunakan antibiotik tunggal seftriakson (Tabel. 2). Dari hasil penelitian, karakteristik pasien dapat dilihat pada Tabel 1. Penggolongan usia pasien yang menggunakan antibiotik, yaitu untuk antibiotik tunggal seftriakson (44,00\%), kombinasi seftriakson-metronidazol $\quad(80,00 \%) \quad$ dan kombinasi sefuroksim-metronidazol (44,44\%) paling banyak pada pasien usia pasien 15-25 tahun (Tabel 1). Sedangkan jenis kelamin yang paling banyak menggunakan seftriakson adalah perempuan dengan jumlah 25 pasien, sedangkan seftriakson-metronidazol sebanyak 9 pasien dan kombinasi sefuroksim-metronidazol 5 pasien (Tabel. 2).

Hasil penelitian menunjukkan bahwa parameter lama hari rawat memiliki perbedaan signifikan secara statistik $(\mathrm{p}<0,000)$ dengan ratarata lama hari rawat terpendek pada pasien apendisitis yang menerima antibiotik kombinasi sefuroksim-metronidazol yaitu 3,00 hari dengan simpangan deviasi 0,5 . Sedangkan rata-rata lama hari rawat yang paling lama adalah pada pasien apendisitis dengan pemberian antibiotik kombinasi seftriakson-metronidazol dengan lama hari rawat 5,60 hari (Tabel 2). Hal ini menunjukkan pasien yang menerima kombinasi sefuroksim-metronidazol memiliki rata-rata lama hari rawat paling singkat. Pada dasarnya lama hari rawat tidak hanya dipengaruhi oleh jenis antibiotik yang diberikan. Keadaan klinis dan hasil laboratorium pasien berhubungan langsung pula dengan lama hari rawat pasien. Lama hari rawat dapat pula dipengaruhi oleh beberapa faktor diantaranya ada atau tidak nya demam, penampilan dan posisi apendiks [11].

Parameter efektifitas berikutnya adalah status pulang pasien, diketahui hasil observasi pasien yang menerima antibiotik tunggal seftriakson memiliki status pulang sembuh paling besar yakni $64,00 \%$ dari total subjek penelitian sementara pasien yang menerima kombinasi seftriakson-metronidazol dan sefuroksimmetronidazol sebagian besar memiliki status pulang membaik masing-masing $80,00 \%$ dan $100,00 \%$ (Tabel 2). Status pulang sembuh berarti pasien dinyatakan sembuh dan diijinkan pulang. Pasien dengan status pulang sembuh seperti yang tertera di rekam medik pasien menunjukkan pasien tidak mengalami komplikasi atau masalah terkait pasca apendiktomi. Hal ini menunjukkan kemungkinan regimen terapi tunggal seftriakson dapat mencegah pasien dari komplikasi pasca apendiktomi. Namun, hal ini perlu dikaji lebih dalam mengingat jumlah sampel yang tidak seimbang pada masing-masing kelompok terapi.

SSI atau infeksi luka operasi merupakan parameter ketiga dalam penelitian ini. Berdasarkan hasil penelitian diketahui terdapat dua pasien yang menerima antibiotik tunggal seftriakson yang mengalami SSI selama MRS (Tabel 2). SSI didefinisikan sebagai infeksi yang muncul dalam jangka waktu hingga 30 hari setelah operasi atau 1 tahun pada kasus implan [12]. Kejadian SSI dapat disebabkan oleh beberapa hal diantaranya durasi pemberian antibiotik profilaksis, stadium penyakit, jenis antibiotik, manajemen sebelum operasi, dan faktor individu pasien [13]. Bakteri penyebab SSI dapat berasal dari autoinfeksi (endogen, self infection) yaitu suatu bakteri yang memang sudah ada di tubuh manusia dan berpindah ke tempat lain di tubuh kita maupun berasal dari eksogen (cross infection) yang berasal dari lingkungan rumah sakit seperti udara ruang operasi, udara ruang rawat inap, peralatan yang tidak steril, maupun petugas rumah sakit yang kurang menerapkan perilaku aseptik dan antiseptik [14]. Kejadian SSI dapat terjadi walaupun telah diberi antibiotik profilaksis maupun antibiotik post operasi, hal ini terjadi karena adanya resistensi bakteri pada 


\section{Zulfa, dkk.}

DOI : https://doi.org/10.24843/JFU.2019.v08.i02.p07

pISSN: 2301-7716; eISSN: 2622-4607

Jurnal Farmasi Udayana, Vol 8, No 2, Tahun 2019, 109-114

antibiotik yang diberikan. Berdasarkan penelitian oleh Chen et al. (2012) tentang re-evaluasi pemberian antibiotik terhadap kejadian SSI, diketahui pada pasien dengan komplikasi SSI terdapat beberapa bakteri aerob yang berhubungan dengan apendisitis diantaranya $E$. coli, K. pneumoniae, Streptococcus, Enterococcus, dan P. aeruginosa. Bakteri Pseudomonas aeruginosa sering tidak tercakup oleh antibiotik profilaksis, bahkan 7 dari 8 jenis bakteri yang ditemukan telah resiten terhadap sefuroksim [15]. Terkait dengan temuan dalam penelitian ini, munculnya SSI pada pasien yang menerima terapi tunggal seftriakson perlu dilakukan pengkajian yang lebih mendalam terkait kondisi klinik pasien dan sensitivitas bakteri yang menginfeksi. Namun hal ini tidak dapat dilakukan karena data bersifat data yang digunakan sekunder. Penelitian oleh Amelia et al. tahun 2016 menyebutkan bahwa faktor yang mempengaruhi munculnya SSI pada pasien apendisitis yang menjalani apendiktomi dengan antibiotik profilaksis ceftriakson adalah faktor jenis kelamin dan durasi operasi [16].

Secara umum ketiga rejimen terapi antibiotik ditinjau dari parameter-parameter diatas dapat dikatakan efektif terlebih seluruh pasien diijinkan pulang dengan kondisi minimum membaik dan kecilnya prevalensi munculnya SSI. Pemilihan rejimen antibiotik untuk apendisitis akut selanjutnya harus memperhatikan analisis efektivitas dan biaya terapi sehingga dapat dicapai terapi yang optimal.

\section{KESIMPULAN}

Dari ketiga parameter efektivitas, penggunaan terapi tunggal seftriakson dirasa lebih efektif karena menunjukkan pasien dengan status pulang sembuh paling banyak, kejadian SSI yang kecil, dan lama hari rawat yang tidak terlalu panjang. Namun terkait perbedaan lama hari rawat yang signifikan, pemilihan antibiotik lebih lanjut lebih baik disertai perbandingan efektifitas dan biaya terapi.

\section{UCAPAN TERIMAKASIH}

Ucapan terimakasih ditujukan pada Akademi Farmasi Surabaya yang telah memberikan dukungan pendanaan dalam skema penelitian internal.

\section{DAFTAR PUSTAKA}

[1] A. Handayana, Deteksi dini dan atasi 31 penyakit bedah saluran cerna (Digestif), Jogjakarta: Andi Offset, 2017, pp. 158-162.

[2] B. Dogra, "Acute Appendicitis: Common Surgical Emergency" Medical Journal of Dr.D.Y.Patil Vidyapeeth, vol 7, no. 6,p.749752,2014.

[3] F. Zulfikar, P.S. Budi dan Wiratmo, "Studi Penggunaan Antibiotik pada Kasus Bedah Apendiks di Instalasi Rawat Inap RSD dr. Soebandi Jember Tahun 2013" E-jurnal Pustaka Kesehatan, vol. 3, no. 1, p. 44-49, 2015.

[4] P. Lemone, Buku ajar keperawatan medical bedah, Edisi 5, Jakarta: Penerbit Buku Kedokteran 2011, pp 833-834.

[5] A. Alkaaki, O.O. Al-Radi, K. Ahmad, A. Alnnawawi, A. Alnawawi, A.Maghrabi, A. Altaf, M. Aljiffry, "Surgical Site Infection Following Abdominal Surgery: A Prospective Cohort Study" Canadian Journal of Surgery, vol. 62, no.2, p.111-117, 2019.

[6] I. Fahrizal, "Perbandingan Pemakaian Ceftriaxone terhadap Infesi Luka Operasi pada Pasien Appendicitis Akut non Komplikata yang dilakukan Laparatomi dan Laparaskopi Apendiktomi" Jurnal Kedokteran Diponegoro. vol. 5, no. 4, p.1007-1012, 2016.

[7] M. I. Hussain, M. Alam, Khurshid, "Role of Postoperative Antibiotics after Appendectomy in Non-Perforated Appendicitis" Journal of the College of Physicians and Surgeons Pakistan, vol. 22, no. 12, p.756-759, 2012.

[8] K.Daskalakis, C. Juhlin, dan L. Påhlman, "The Use of Pre- or Postoperative Antibiotics in Surgery for Appendicitis : A Systematic Review", Scandinavian Journal of Surgery, vol.103, p14-20, 2013.

[9] MA. Liberman, KL. Greason, S. Frame et al, "Single-dose cefotetan or cefoxitin versus multiple-dose cefoxitin as prophylaxis in patients undergoing appendectomy for acute nonperforated appendicitis", J Am Coll Surg, vol.180, no.1, 1995. 


\section{Zulfa, dkk.}

DOI : https://doi.org/10.24843/JFU.2019.v08.i02.p07

pISSN: 2301-7716; eISSN: 2622-4607

Jurnal Farmasi Udayana, Vol 8, No 2, Tahun 2019, 109-114

[10] H. G. Garcell, A. V. Arias, C. A. P. Sandoval, A. B. Sado, R. N. A. Serrano, F. G. García, "Risk Factors for Surgical Site Infection After Appendectomy for Acute Appendicitis; Results of a Cross-Sectional Study Carried out at a Community Hospital in Qatar (2013-2016)" Hospital Practices and Research, vol.4, no. 2. P.45-49. 2019.

[11] P. Amaral, E. M.A. Filho, T.D. Galvao, E. E. Junior, G. E. J. M. Neto, F. Mascarenhas, dan E. Fahel, "Factors Leading to Long-Term Hospitalization After Laparoscopic Appendectomy", Journal of the Society of Laparoendoscopic Surgeous, vol.2006, no. 10, p.355-358, 2006.

[12] A. Koirala, D. Thakur, S. Agrawal, B.L Chaudhary, dan S.Poudal, "Surgical Site Infection in Laparoscopic Versus Open Appendictomy", Journal of Nobel Medical College, vol. 7, no. 13, p. 39-43, 2018.

[13] M. Rafiq, M. M. Khan, A. Khan, dan H. Jan, "Evaluation of Postoperative
Antibiotics after Non-perforated Appendictomy", J Pak Med Asssoc, vol. 65, no. 8, p. 815-817, 2015.

[14] N. Poluan, J. Penelewen, E.P. Sitanggang, "Analisis Pencegahan Infeksi Daerah Operasi (IDO) di Instalasi Bedah Sentral Rumah Sakit Prof. Dr. R. D. Kandou Kota Manado", Paradigma, vol. 1, no.5, p. 12-27, 2016.

[15] C.Y. Chen, Y.C. Chen, H.N. Pu, C.H. Tsai, W.T. Chen, dan C.H. Lin, "Bacteriology of Acute Appendicitis and Its Implication for the Use of Prophylactic Antibiotics", Surgical Infection, vol. 13, no. 6, p.383-390, 2012.

[16] E. Amelia, B. Arianto, dan A. Purnamayanti, "The Suitability and Efficacy of Perioperative Antibiotics in Relation with the Surgical Wound after Appendectomy", International Journal of Pharma Medicine and Biological Sciences, vol. 5, no. 4, 2016. 